\title{
PERAN FACEBOOK DALAM KAMPANYE POLITIK PEMILUKADA DI KABUPATEN OGAN KEMIRING ULU
}

\author{
Hendra Alfani \\ Program Studi Ilmu Komunikasi FISIP Universitas Baturaja \\ Email: hefanila@yahoo.co.id
}

ARTICLE INFO ABSTRACT

Keywords:

Facebook, political campaign, election.

\begin{abstract}
Facebook, one of social media, becomes a new space for everyone to interact and socialize without being limited by space and time, like in conventional media (mainstream). In its development, social media is also used to support political campaign in general election of regional head (Pemilukada). In addition to reaching the audience without being limited space and time, the cost is also cheap and efficient. Facebook has been chosen by candidates for regional heads as a medium of communication and socialization, not just relying on television media, advertisements in newspapers, banners, billboards, and other media. Candidates also take advantage of social media technology through facebook with the aim to provide access to information for public through cyberspace. The use of facebook is also done by the pair of candidates in the regional head election of Ogan Komering Ulu (OKU) South Sumatra Province in 2015. This study found the use of facebook is quite significant by both pairs of candidates in the election $O K U$ in order socialization and political campaign.
\end{abstract}

\section{Pendahuluan}

Eskalasi politik dalam pelaksanaan Pemilihan Umum Kepala Daerah (Pemilukada) serentak 9 Desember 2015, sangat kuat terasa. Dua pasang calon bupati dan wakil bupati yang sudah dinyatakan lolos dan mendapat nomor urut pasangan calon untuk berkompetisi dalam Pemilukada Kabupaten Ogan Komering Ulu (OKU) 2015, adalah pasangan Drs. H. Kuryana Aziz - Drs. Johan Anuar, S.H., M.M. (Paslon Nomor Urut 1) dan pasngan Hj. Percha Leanpuri, B.Bus., M.B.A. - Drs. H.M. Nasir Agun, M.B.A. (Paslon Nomor Urut 2). Pasangan Kuryana-Johan diajukan oleh gabungan 6 (enam) partai politik, yaitu PDI-P, Golkar, Demokrat, Gerindra, PPP, dan Nasdem. Sedangkan pasangan Percha-Nasir di ajukan oleh koalisi partai politik, yaitu PKS, PKB, PAN, PBB, HANURA, dan PKPI.

Partai politik menjalankan beberapa fungsi yaitu sebagai sarana komunikasi politik, sebagai sarana sosialisasi politik, sebagai sarana rekruitmen politik, dan sebagai sarana pengatur konflik (Budiardjo, 2008:405-409). Fungsi komunikasi politik adalah salah satu fungsi yang penting dari partai politik. Era digital menjadi penanda kuatnya peran teknologi informasi dan komunikasi dalam memengaruhi pelaksanaan pemilukada serentak tahap pertama tahun 2015, partai politik juga merambah media online (internet) untuk berkomunikasi dengan khalayak luas, salah satunya adalah facebook. Gabungan parpol pengusung dan pendukung pasangan calon nomor urut 1, Kuryana-Johan, dan pasangan calon nomor urut 2, Percha-Nasir juga menggunakan facebook sebagai saluran komunikasi politik (sosialisasi dan kampanye politik) dalam menyampaikan pesannya mengenai calon bupati dan wakil bupati yang diusung pada pemilukada OKU tahun 2015.

Di Indonesia, pengguna media sosial memang terus tumbuh. Data Kementerian Komunikasi dan Informatika pada 2013 menunjukkan, setidaknya ada 63 juta pengguna internet di Indonesia. Sebanyak 95\% di antaranya menggunakan internet untuk mengakses situs jejaring sosial. Oleh karena itu, kemunculan ruang publik digital tersebut juga membuka kesempatan bagi politisi untuk berkampanye (kompas.com).

Jumlah pengguna Facebook terus meningkat di setiap tahunnya. Pada tahun 2012 pengguna Facebook tercatat 44,6 juta pengguna dan di tahun 2014 pengguna Facebook telah mencapai 62 juta pengguna. Semakin bertambahnya pengguna Facebook di Indonesia merupakan salah satu peluang bagi partai politik di Indonesia menjadikan Facebook sebagai media komunikasi politik bagi kepada 
khalayak khususnya kelompok pemilih potensial. Pengguna terbesar Facebook adalah populasi masyarakat berumur 18-50 tahun yang merupakan kategori pemilih potensial (terbesar) dalam pemilu ataupun pemilukada. Bahkan Komisioner Komisi Pemilihan Umum (KPU) mengungkapkan bahwa untuk segmen pemilih 18-25 tahun jumlah pemilih pemula pada Pemilu 2014 mencapai 14 juta jiwa (Kompas.com, 2013).

Catatan The Wall Street Journal, menunjukkan bahwa jumlah pengguna Facebook di Indonesia sampai dengan bulan Juni 2014 sudah mencapai angka 69 juta anggota. Jumlah tersebut tentu saja terus bertambah dari tahun ke tahun. Saat berkunjung ke Indonesia, sekitar Bulan Oktober 2014, CEO Facebook Mark Zuckerberg mengatakan bahwa Indonesia merupakan pasar yang potensial, karena jumlah tersebut terbilang baru sedikit bila dibandingkan dengan penetrasi internet dan jumlah penduduk Indonesia yang mencapai 240 juta orang.

\subsection{Fokus Masalah Penelitian}

Berdasarkan latar belakang masalah di atas, maka penulis merumuskan fokus masalah penelitian sebagai berikut: (1). Bagaimana partai politik (parpol) pengusung dan pendukung kedua pasangan calon Bupati dan Wakil Bupati OKU dalam Pemilukada serentak 2015 memanfaatkan jejaring sosial facebook yang dikelola oleh koalisi parpol pengusung/pendukung pasangan calon untuk mensosialisasikan dan mengkampanyekan pasangan calon yang diusung guna mendapatkan respon atau umpan balik yang positif serta dukungan yang signifikan dari pemilih pada pemilukada OKU 9 Desember 2015, dan (2). Bagaimana peran Facebook yang dikelola koalisi parpol pengusung/pendukung pasangan calon sebagai sarana komunikasi politik terhadap pemilih dalam pemilukada Kabupaten OKU 9 Desember 2015.

\subsection{Tujuan Penelitian}

Tujuan penelitian ini adalah sebagai berikut: (1). Mengetahui bagaimana parpol memanfaatkan jejaring sosial facebook yang dikelola oleh koalisi parpol pengusung/pendukung pasangan calon untuk mensosialisasikan dan mengkampanyekan pasangan calon Bupati dan Wakil Bupati yang diusung guna mendapatkan respon atau umpan balik yang positif serta dukungan yang signifikan dari pemilih pada pemilukada Kabupaten OKU 9 Desember 2015, dan (2). Mengetahui bagaimana peran facebook yang dikelola koalisi parpol pengusung/pendukung pasangan calon sebagai sarana komunikasi politik terhadap pemilih dalam pemilukada Kabupaten OKU 9 Desember 2015.

\section{Tinjauan Pustaka}

\subsection{Sejarah dan Pengertian Facebook}

Facebook menurut wikipedia berbahasa Indonesia adalah sebuah layanan jejaring sosial dan situs web yang diluncurkan pada 4 Februari 2004. Facebook didirikan oleh Mark Zuckerberg, seorang mahasiswa Harvard kelahiran 14 Mei 1984 bersama teman sekamarnya dan sesama mahasiswa Universitas Harvard, Eduardo Saverin, Andrew McCollum, Dustin Moskovitz, dan Chris Hughes. Pada awal masa kuliahnya, situs jejaring sosial ini keanggotaannya masih dibatasi untuk mahasiswa dari Harvard College. Dalam dua bulan selanjutnya, keanggotaannya diperluas ke sekolah lain di wilayah Boston (Boston College, Universitas Boston, MIT, Tufts), Rochester, Stanford, NYU, Northwestern, dan semua sekolah yang termasuk dalam Ivy League.

Sampai akhirnya, pada September 2006, Facebook mulai membuka pendaftaran bagi siapa saja yang memiliki alamat email. Fitur yang ditawarkan Facebook sebagai situs jejaring sosial membuat banyak orang menggunakannya. Situs ini secara perlahan membuka diri kepada mahasiswa di universitas lain sebelum dibuka untuk siswa sekolah menengah atas, dan akhirnya untuk setiap orang yang berusia minimal 13 tahun. Meski begitu, menurut survei Consumer Reports bulan Mei 2011, ada 7,5 juta anak di bawah usia 13 tahun yang memiliki akun Facebook dan 5 juta lainnya di bawah 10 tahun, sehingga melanggar persyaratan layanan situs ini.

Pada September 2012, Facebook memiliki lebih dari satu miliar pengguna aktif, lebih dari separuhnya menggunakan telepon genggam. Pengguna harus mendaftar sebelum dapat menggunakan situs ini. Setelah itu, pengguna dapat membuat profil pribadi, menambahkan pengguna lain sebagai teman, dan bertukar pesan, termasuk pemberitahuan otomatis ketika mereka memperbarui profilnya. Selain itu, pengguna dapat bergabung dengan grup pengguna dengan ketertarikan yang sama, 
diurutkan berdasarkan tempat kerja, sekolah atau perguruan tinggi, atau ciri khas lainnya, dan mengelompokkan teman-teman mereka ke dalam daftar seperti "Rekan Kerja" atau "Teman Dekat".

Studi Compete.com bulan Januari 2009 menempatkan Facebook sebagai layanan jejaring sosial yang paling banyak digunakan menurut jumlah pengguna aktif bulanan di seluruh dunia. Entertainment Weekly menempatkannya didaftar "terbaik" akhir dasawarsa dengan komentar, "Bagaimana caranya kita menguntit mantan kekasih kita, mengingat ulang tahun rekan kerja kita, mengganggu teman kita, dan bermain Scrabulous sebelum jejaring sosial Facebook diciptakan?"

Quantcast memperkirakan Facebook memiliki 138,9 juta pengunjung bulanan di AS pada Mei 2011. Menurut Social Media Today pada April 2010, sekitar 41,6\% penduduk Amerika Serikat memiliki akun Facebook. Meski begitu, pertumbuhan pasar Facebook mulai turun di sejumlah wilayah dengan hilangnya 7 juta pengguna aktif di Amerika Serikat dan Kanada pada Mei 2011.

Nama layanan ini berasal dari nama buku yang diberikan kepada mahasiswa pada tahun akademik pertama oleh beberapa pihak administrasi universitas di Amerika Serikat dengan tujuan membantu mahasiswa mengenal satu sama lain. Facebook memungkinkan setiap orang berusia minimal 13 tahun menjadi pengguna terdaftar di situs ini.

Tabel 1.

Jumlah Pengguna Facebook di Indonesia

\begin{tabular}{cccl}
\hline No. & Tahun & Jumlah Pengguna (juta) & \multicolumn{1}{c}{ Sumber } \\
\hline 1. & 2010 & 17,6 & Jubilee Enterprise \\
2. & 2012 & 44,6 & Wikipedia \\
3. & 2014 & 69 & The Wall Street Journal \\
\hline
\end{tabular}

Sumber: Olah data, 2015

Dewasa ini penggunaan situs jejaring sosial sebagai media berinteraksi sosial secara online sudah begitu meluas bahkan mendunia. Banyak manfaat yang bisa didapat dengan bergabung dalam situs jejaring sosial seperti Facebook ini. Diantaranya dapat berkoneksi dengan teman, baik itu teman baru atau lama, keluarga, dan lain-lain tanpa terhalang oleh jarak tempat. Selain itu, kita juga bisa memanfaatkan banyak fitur hiburan yang tersedia secara gratis. Diantaranya quiz, games, chat, dan masih banyak yang lainnya. Game yang menjadi favorit Facebooker diantaranya Texas Hold'em Poker (Zynga Poker), Farmville, dan lain-lain.

Bagi para remaja, Facebook juga difungsikan sebagai ajang narsis biar eksis. Diantaranya dengan mengupload koleksi foto pribadinya yang biasanya tak jarang merupakan hasil editan. Bagi yang tak suka narsis dan eksis biasanya lebih suka menggunakan avatar atau gambar binatang lucu untuk foto profilenya. Sekedar info, untuk mengedit foto secara online ataupun membuat avatar silahkan anda kunjungi halaman berikut daftar situs edit foto online.

\subsection{Kampanye di Media Sosial (Online)}

Douglas Hagar (2014) dalam Campaigning Online: Social Media in the 2010 Niagara Municipal Elections (dalam Berliani Ardha, 2014:108), menuturkan bahwa media sosial bisa berkontribusi pada keberhasilan politik. Ini karena media sosial membuat kandidat dalam sebuah pemilihan bisa berinteraksi dengan para calon pemilih dengan skala dan intensitas yang tak bisa dicapai lewat pola kampanye tradisional seperti kampanye dari pintu ke pintu, brosur, bahkan peliputan oleh media cetak dan televisi. Selain itu, biaya kampanye media sosial juga jauh lebih murah karena tidak ada biaya yang langsung diasosiasikan dengan media sosial semacam Facebook, Twitter, dan Youtube. Media sosial juga unggul karena memberi kesempatan para calon pemilih untuk berdialog dua arah dengan kandidat, tidak seperti model kampanye tradisional yang cenderung searah, dari kandidat ke calon pemilih. Sifat komunikasi politik antara kandidat dan calon pemilih bisa menjadi multiarah, seperti dari kandidat ke pemilih, pemilih ke kandidat, atau antarpemilih.

Modal komunikasi multiarah ini, menurut Tasente Tanase (2015) dalam The Electoral Campaign through Social Media: A Case Study-2014 Presidential Election in Romania, menjadi salah satu modal bagi kandidat untuk bisa meraih suara dalam pemilihan. Tasente berargumen, peluang dukungan media sosial menjadi suara dalam pemilihan lebih besar jika ada keterlibatan atau partisipasi 
aktif calon pemilih. Partisipasi aktif ini tidak harus berlangsung di akun media sosial si kandidat. Bisa saja pendukung kandidat itu menyebarluaskan materi kampanye dari akun kandidat, tetapi dengan pesan yang dipersonalisasi lalu memancing perbincangan dengan teman-temannya di dunia maya. Dengan kata lain, keaktifan itu lebih penting dari banyaknya orang yang menjadi "pengikut" di akun media sosial (Kompas.com). Tasente juga mengatakan dukungan di dunia maya tidak berdiri sendiri. Tidak selalu kesuksesan kampanye di media sosial otomatis membuat kandidat menang dalam sebuah pemilihan. Kampanye di media sosial juga harus diikuti dengan triangulasi metode kampanye. Artinya, kampanye media sosial yang gencar juga harus diikuti kampanye tatap muka ataupun bentuk kampanye tradisional lainnya. Ini karena penelitian di beberapa negara juga menunjukkan modal kampanye yang besar justru mendominasi tingkat keterpilihan ketimbang media sosial (dalam Berliani Ardha, 2014:108).

Penggunaan media sosial di Indonesia untuk kampanye bukan hal yang benar-benar baru. Hanya saja, baru pada pemilihan kepala daerah serentak 2015, Komisi Pemilihan Umum mengatur penggunaannya di dalam Peraturan Komisi Pemilihan Umum (PKPU) Nomor 7 Tahun 2015 tentang Kampanye Pilkada. PKPU itu menyebutkan, tim sukses wajib mendaftarkan akun resmi di media sosial kepada KPU daerah paling lambat sehari sebelum pelaksanaan kampanye. Selain itu, diatur pula konten kampanye serta durasi kampanye di media sosial. Pada pemilihan kepala daerah serentak kali ini, Badan Pengawas Pemilihan Umum (Bawaslu) mencatat sebanyak 26\% dari 105 calon kepala daerah di 58 kabupaten dan kota dijadikan sample pengawasan menggunakan media sosial sebagai sarana kampanye. Dari jumlah itu, sebanyak 57\% menggunakan Facebook dan 27\% menggunakan Twitter.

Ketua Bawaslu Muhammad menuturkan, kesempatan kampanye media sosial bagi para calon juga memberi tantangan bagi pengawas pemilihan umum. Ini karena panitia pengawas juga punya keterbatasan dalam menertibkan secara langsung akun media sosial. Untuk itu, Bawaslu menggandeng lembaga negara terkait yang berhubungan dengan media secara umum dan jurnalisme khususnya. Kampanye media sosial juga membuka peluang/potensi munculnya konsultan-konsultan media sosial yang menggerakkan pasangan calon. Mengenai hal itu, Komisioner KPU Hadar Nafis Gumay mengaku belum ada pengaturan khusus. Hanya saja, jika konsultan-konsultan media sosial masuk dalam tim kampanye atau jasa konsultasi itu bagian dari lembaga survei, mereka harus mendaftar ke KPU.

\subsection{Partisipasi Politik, Media Baru dan Demokrasi}

Menurut McQuail (2012:165), media massa pers dan siaran awal secara luas dipandang menguntungkan (bahkan perlu) bagi berjalannya politik yang demokratis. Keuntungan berasal dari arus informasi tentang peristiwa publik kepada semua warga negara dan terbukanya politikus dan pemerintah bagi sorotan dan kritik publik. Media elektronik baru secara luas disambut sebagai cara yang potensial untuk lari dari politik "top-down" yang opresif dari demokrasi massa, di mana partai politik yang terorganisasi secara ketat membuat kebijakan secara sepihak dan memobiliasi dukungan di belakang mereka dengan perundingan dan masukan akar rumput yang minimal. Mereka menyediakan alat untuk penyediaan informasi politik dan gagasan yang sangat dibedakan, akses yang hampir tidak terbatas dalam teori untuk semua suara, dan banyak umpan balik dan perundingan antara pemimpin dan pengikut. Mereka menjanjikan forum-forum bagi perkembangan kelompok kepentingan dan pembentukan opini. Mereka memungkinkan dialog berlangsung antara politikus dan warga negara yang aktif tanpa campur tangan mesin partai yang tak terhibdarkan. Coleman (1999) menunjukkan "peran media baru dalam layanan subversif dari ekspresi bebas di bawah persyaratan kontrol otoriter alat-alat komunikasi" yang tidak kalah penting. Tidak mudah bagi pemerintah untuk mengendalikan akses pada dan pengguna internet oleh warga negara yang berbeda pendapat, tetapi juga bukannya hal tersebut tidak mungkin.

Perkembangan teknologi media baru (new media) menghasilkan perubahan besar dalam pengalaman politik masyarakat. Media baru dirancang untuk menigkatkan jangkauan, kecepatan dan efisiensi komunikasi manusia, memiliki potensi untuk memperkuat dan meningkatkan mutu demokrasi. Bahkan menurut Alwi Dahlan (1999), komunikasi adalah tulang punggung demokrasi; seluruh proses demokrasi dilangsungkan dengan komunikasi. Kemajuan teknologi yang sangat cepat akhir-akhir ini telah mendorong globalisasi informasi, yang pada gilirannya membawa tekanan yang intens terhadap Negara berkembang untuk reformasi ke arah demokrasi Barat. Teknologi media baru, 
menurut Dahlan, makin banyak diterapkan dalam proses demokrasi di Asia - meskipun tidak selalu berhasil baik dan kadang-kadang dapat juga menimbulkan akibat yang justru tidak membantu pertumbuhan demokrasi (dalam Salim Alatas, 2014).

Para ahli memandang bahwa hubungan media baru dan demokrasi dalam berbagai konteks politik, internet atau media digital memiliki potensi untuk meningkatkan komunikasi publik dan memperkaya demokrasi. Penelitian awal mengenai potensi internet untuk membentuk kembali demokrasi, menurut Aeron Davis, sangat dipengaruhi oleh nilai-nilai normatif yang disajikan dalam karya langsung para pembela demokrasi danruang publik seperti Habermas, Bohman, Dryzek, Putnam. Mereka berpendapat bahwa Teknologi Komunikasi dan Informasi (ICT) menawarkan perangkat untuk menerapkan teori mengenai demokrasi dan ruang publik, khususnya mengenai partisipasi masyarakat yanglebih inklusif dan pertukaran deliberatif antara warga negara biasa dan elit politik. Dengan demikian, secara teorits, internet memiliki potensi untuk pembaharuan dan pengembangan demokrasi (Salim Alatas, 2014).

Penegasan McQuail, bahwa gagasan tentang ranah publik dan masyarakat sipil (civil society) yang dibahas dimana-mana telah menstimulasi gagasan bahwa media baru secara ideal sesuai untuk menempati ruang masyarakat sipil di antara ranah pribadi dan ranah kegiatan negara. Gagasan ideal tentang ranah publik sebagai arena terbuka bagi percakapan publik, debat dan, pertukaran gagasan terlihat dapat dipenuhi oleh bentuk-bentuk komunikasi (khususnya Internet) yang memungkinkan warga negara mengekspresikan pandangan mereka dan saling berkomunikasi dengan para pemimpin politik mereka tanpa meninggalkan rumah masing-masing (2012:165-166).

Argumen untuk menyambut "politik baru" yang berlandaskan media baru cukup beragam dan melibatkan perspektif yang berbeda-beda. Dahlberg (2001) menggambarkan tiga model dasar. Pertama, terdapat model "libertariannisme-cyber" (cyber-libertarianism) yang menginginkan pendekatan terhadap politik berdasarkan model pasar konsumen. Survei, pemungutan suara, dan televoting cocok untuk pandangan ini, menggantikan proses yang lebih lama. Kedua, terdapat pandangan "komunitarian" (communitarian) yang mengharapkan keuntungan datang dari partisipasi dan masukan akar rumput yang lebih besar dan penguatan komunitas politik yang lebih lokal. Ketiga, terdapat keuntungan yang dirasakan atas "demokrasi keterlibatan" yang dimungkinkan dengan meningkatkan teknologi untuk interaksi dan pertukaran ide dalam ranah publik (Coleman, 2001; dalam McQuail, 2012:166).

Gonjang-ganjing dunia politik di Indonesia membawa sebuah pengaruh sosial yang luas di kalangan masyarakat. Media sosial turut ambil bagian sebagai alat komunikasi yang efektif dipilih masyarakat untuk menyalurkan pendapat dan aspirasinya. Informasi yang beredar di media sosial segera mendapat tanggapan atau feedback yang cepat dan langsung. Terjadi komunikasi tidak hanya dua arah namun juga komunikasi kolektif dari sekelompok orang yang memiliki ketertarikan yang sama. Media sosial sebagai perkembangan dari teknologi internet merupakan media baru yang memberikan alternatif bentuk komunikasi yang dinamis kepada masyarakat. Media memiliki perspektif yang menjadi kerangka acuan dalam kegiatannya, yang sangat berhubungan dengan dukungan atau penolakan atas ide tertentu. Media memiliki kemampuan untuk membentuk pendapat umum. Adanya pendapat umum dengan snowball effect akan sangat mungkin mendorong sikap dan perilaku khalayak atas isu politik tertentu.

Kehadiran media sosial, seperti Facebook, Twitter, YouTube serta Blog, partisipasi politik masyarakat khususnya kaum muda melalui internet meningkat pesat. Partisipasi politik melalui sosial media di Indonesia merupakan satu hal yang sempat menjadi fenomena beberapa saat lalu, ketika warga melancarkan desakkan politik dan memobilisasi opini publik secara online. Meskipun gerakan politik tersebut tidak selalu berhasil dalam mengusung isu-isu politik tertentu untuk menekan pemerintah, namun tidak jarang gerakan melalui media sosial berhasil mendesak pemerintah untuk mengubah kebijakan-kebijakan yang kontroversial tersebut. Gerakan politik melalui media sosial tersebut merupakan sebuah bentuk dari cyberdemocracy, cyberpolitic, atau cyberprotest di Indonesia.

Kita tentu ingat kasus beberapa kasus seperti Prita Mulya Sari yang menuai dukungan publik lewat media sosial, atau gerakan \#ShameOnYouSBY yang menjadi protes masyarakat terhadap UU Pilkada Tidak Langsung berhasil memaksa Presiden SBY diakhir masa jabatannya mengeluarkan sebuah Perppu. Lalu kasus yang paling hangat terjadi adalah kasus di tangkapnya pemimpin KPK, Bambang Widjojanto yang memunculkan gerakan \#SaveKPK di media sosial. Gerakan di dunia maya ini mempengaruhi terhadap reaksi masyarakat di dunia nyata dengan menggalang aksi massa. 
Masyarakat dipersatukan oleh tujuan dan pemikiran yang sama sehingga menimbulkan gerakan masif yang tidak terbendung.

Partisipasi politik mungkin tampak terlihat sederhana, yaitu bagaimana warga negara mengambil bagian dalam proses perumusan dan penerapan kebijakan publik. Pandangan tersebut menunjukkan persyaratan bahwa partisipasi politik harus melibatkan beberapa derajat efektivitas dan intensionalitas minimal dalam memberikan kontribusi bagi pembuatan kebijakan publik. Moyser, George Political Participation dalam Roland Axtmann (ed). Understanding Democratic Politics: An Introduction, menggolongkan partisipasi politik dalam dua level: Pertama, apa yang disebut partisipasi politik selalu melibatkan informasi yang baik yang digunakan oleh warga negara yang bertanggung jawab dan terbuka untuk kepentingan bersama. Dalam konteks ini, partisipasi politik hanya terjadi jika dilakukan secara bertanggung jawab untuk menghasilkan informasi yang baik. Dengan demikian, partisipasi berkaitan dengan upaya untuk meningkatkan pengetahuan politik (political knowledge). Kedua, berkaitan dengan dampak yang muncul dari partisipasi politik terhadap pengambilan kebijakan publik. Partisipasi politik harus memiliki dampak, setidaknya untuk meningkatkan kesadaran politik dan serta memberikan pengetahuan kepada publik.

\section{Hasil Penelitian Dan Pembahasan}

\subsection{Facebook sebagi media komunikasi politik paslon}

Model komunikasi yang digunakan dalam penelitian ini adalah model komunikasi Lasswell. Alur model komunikasi menurut Harold Lasswell adalah Who (Siapa), Say What (Mengatakan Apa), In Which Channel (Menggunakan saluran apa), To Whom (Untuk siapa), With What Effect (Dengan atau mengahasilkan efek apa), (Mulyana 2007:69). Analisis terkait model komunikasi ini adalah: (1). Who, pada penelitian ini pihak yang mempunyai kebutuhan untuk menyampaikan pesan adalah parpol pengusung pasangan calon (paslon) Bupati dan Wakil Bupati, (2). Say What, parpol pengusung mengkomunikasikan pesan tentang calon Bupati dan Wakil Bupati yang diusung, pesan tersebut berupa poster/foto paslon, pesan tertulis/komentar yang diposting di Facebook, Link Iklan paslon di media cetak, Link berita mengenai paslon dari portal berita online, (3). In Which Channel, dalam penelitian ini parpol pengusung menggunakan Facebook sebagai alat menyampaikan pesan, (4). To Whom, dalam penelitian ini orang yang menerima pesan dari sumber adalah fans/pendukung, simpatisan, relawan, tim sukses dan seluruh elemen masyarakat khususnya kategori pemilih potensial, dan (5). With What Effect, dalam penelitian ini efek yang diharapkan adalah citra positif paslon yang diusung dan partisipasi dari pemilih potensial dalam pemilu pemilukada Kabupoaten OKU 2015.

Menurut peneliti, facebook sebagai salah satu media jejaring sosial yang digunakan sebagai media komunikasi politik parpol pengusung paslon bupati dan wakil bupati, sudah melaksanakan fungsi komunikasi politik secara siginifikan. Fungsi komunikasi politik menurut McNair (dalam Cangara, 2011:33) adalah: (1). Memberikan informasi kepada khalayak tentang apa yang terjadi disekitarnya. Pengelola Facebook paslon Kuryana-Johan dan Percha-Nasir (walaupun masih kurang mendalam) secara seksama sudah melakukan pengamatan dan monitoring tentang apa yang terjadi dalam masyarakat khususnya pemilih potensial yang mempunyai porsi cukup besar dalam pemilukada Kabupaten OKU 2015. Pengamatan dan monitoring berkaitan dengan isi pesan yang tepat untuk disampaikan kepada target komunikasi politik. Setelah melakukan observasi pada akun Facebook parpol pengusung paslon, ditemukan isi pesannya fokus memengaruhi sikap pada lapisan pemilih potensial. Facebook parpol pengusung paslon mengkomunikasikan visi-misi dan berbagai informasi positif calon bupati dan wakil bupati yang diusung melalui link yang di Facebook, (2). Memberi pendidikan kepada khalayak terhadap arti dan signifikansi fakta yang terjadi. Walaupun belum maksimal (masih banyak pernyataan, status ataupun tanggapan yang "emosional"), akan tetapi Facebook parpol pengusung kedua paslon sudah berusaha maksimal untuk memberikan pendidikan politik kepada pemilih potensial yang masih kurang aware dengan politik. Parpol pengusung paslon semestinya dapat memaksimalkan fungsi tersebut untuk memberikan pendidikan politik kepada pemilih potensial sehingga pemilih aware, kemudian dapat memberikan citra positif yang produktif kepada masing-masing paslon, (3). Menyediakan diri sebagai platform politik untuk menampung masalah-masalah politik sehingga dapat menjadi bahasan dalam membentuk opini publik dan menyampaikan hasil opini publik kepada masyarakat. Dalam pengamatan, fungsi politik ini dalam Facebook parpol pengusung kedua paslon sudah berjalan, walaupun masih kurang optimal. Hal ini 
disebabkan karena aspirasi dan suara dari masing-masing pendukung tidak dimobilisasi dengan baik oleh admin Facebook parpol pengusung paslon, diduga adanya keterbatasan-keterbatasan, sehingga adanya bahasan diskusi atau tanggapan yang cenderung bias, (4). Menjadi sarana publikasi kepada seluruh lapisan calon pemilih. Fungsi ini sudah dilaksanakan oleh Facebook parpol pengusung kedua paslon sebagai salah satu media komunikasi politik bagi paslon. Berbagai agenda kampanye paslon, visi-misi dan program-program kepemimpinan untuk memenangkan pemilukada OKU 2015 dipublikasikan melalui Facebook parpol pengusung paslon, dan (5). Media politik berfungsi sebagai saluran advokasi yang membantu agar kebijakan dan program politik dapat disalurkan kepada seluruh lapisan masyarakat melalui media massa. Berdasarkan observasi pada akun-akun Facebook parpol pengusung kedua paslon mengkomunikasikan informasi yang berkaitan dengan visi-misi dan program serta agenda calon bupati dan wakil bupati yang diusung.

\subsection{Facebook sebagai salah satu media jejaring sosial untuk mencari informasi}

Pemilih aktif menggunakan Facebook sebagai sarana mencari informasi karena mudah mengakses, jaringannya luas, sangat ekonomis, dan membuat komunikasi lebih cepat. Berdasarkan hasil penelitian tentang alasan mengapa narasumber aktif mencari informasi melalui Facebook, pemilih aktif mencari informasi mengenai isu politik melalui Facebook parpol pengusung paslon antara lain karena pemilih pendukung ingin mengetahui hal-hal baru dan informasi penting tentang paslon, Facebook digunakan sebagai bahan referensi dan pemantapan narasumber dalam memilih paslon, bahan observasi pribadi, dan Facebook digunakan untuk mengikuti perkembangan pelaksanaan pemilukada di OKU.

Alasan pemilih di atas sesuai dengan teori kegunaan dan gratifikasi menurut (West dan Turner, 2008:101) menyatakan bahwa: "Orang secara aktif mencari media tertentu dan muatan (isi) tertentu untuk menghasilkan kepuasan (atau hasil) tertentu". Pemilih pendukung Facebook paprpol pengusung paslon menggunakan Facebook untuk mendapatkan informasi mengenai pasangan calon.

\subsection{Fungsi Facebook sebagai media komunikasi politik}

Facebook telah menjadi saluran komunikasi politik antar pemilih dengan politisi (paslon bupati dan wakil bupati). Berdasarkan hasil pengamatan, facebook digunakan sebagai sarana pencarian informasi tentang paslon oleh pemilih pendukung paslon. Facebook digunakan untuk komunikasi antar pemilih atau pendukung paslon. Dalam konteks ini facebook parpol pengusung paslon juga digunakan sebagai alat mobilisasi. Dukungan dari pemilih terhadap pesan yang disampaikan melalui facebook berupa like pada postingan facebook parpol pengusung paslon. Dukungan yang diberikan melalui comment diakomodasi oleh admin facebook parpol pengusung paslon. Ada interaksi yang terjalin antara pendukung dan admin facebook. Beberapa kelebihan facebook sebagai media komunikasi politik sudah digunakan secara maksimal oleh pengelola/admin facebook parpol pengusung paslon.

Jika kelebihan facebook sebagai media yang gratis, mudah, murah, jangkauannya luas ini dikelola dengan maksimal, interaktivitas dijaga, isi pesan disesuaikan sesuai target yang akan disasar, diskusi terjalin efektif, aspirasi, opini, kritik dan saran dari pendukung dimobilisasi dengan baik pasti akan menciptakan efek positif yang ingin dicapai oleh masing-masing pasangan calon bupati dan wakil bupati yaitu partisipasi politik dan dukungan pada pemilukada Kabupaten OKU 2015.

\subsection{Minat dan Keputusan Pemilih Pendukung}

Facebook dalam observasi ini digunakan sebagai alat atau media komunikasi politik untuk menyampaikan pesan politik pasangan calon bupati dan wakil bupati dalam pemilukada Kabupaten OKU 2015. Selaras dengan konsep komunikasi pemasaran, dalam komunikasi politik untuk menyampaikan pesan politiknya yaitu calon calon bupati dan wakil bupati juga selaras dengan konsep AIDA yaitu; Attention, Interest, Desire, Action (Kotler, 2003:568). Facebook parpol pengusung paslon menyampaikan pesan tentang calon calon bupati dan wakil bupati yang diusung. Pesan tersebut berupa poster/foto, link berita yang berisi informasi tentang calon bupati dan wakil bupati yang diusung. Berdasarkan hasil pengamatan pasangan calon bupati dan wakil bupati yang dikomunikasikan melalui facebook parpo pengusung paslon berhasil mendapatkan atensi dari pemilih/pendukung.

Pemilih (pendukung dan simpatisan) dapat memberikan penilaian atas calon bupati dan wakil bupati yang diusung parpol pada facebook partai pengusung paslon. Setelah memberikan penilaian dan 
mendapatkan informasi dari facebook partai pengusung paslon tentang calon bupati dan wakil bupati yang diusung oleh paprpol, pendukung memilki minat yang kuat untuk mendukung calon bupati dan wakil bupati yang diusung. Informasi tentang calon bupati dan wakil bupati yang dikomunikasikan melalui facebook parpol pengusung paslon memberikan referensi kepada pendukung tentang calon bupati dan wakil bupati yang diusung.

Pendukung facebook parpol pengusung paslon dapat melakukan pengambilan keputusan terhadap calon bupati dan wakil bupati yang diusung oleh parpol. Facebook sebagai salah satu media komunikasi politik parpol pengusung paslon mengkomunikasikan informasi yang bersangkutan dengan calon bupati dan wakil bupati yang diusung oleh gabungan parpol. Informasi yang dibagikan melalui facebook berperan mempengaruhi minat dan keputusan pendukung facebook parpol pengusung dalam pengambilan keputusan terhadap calon bupati dan wakil bupati yang diusung oleh parpol pengusung.

\subsection{Kebijakan dan Program Politik Paslon}

Agenda parpol pengusung paslon dalam pemilukada Kabupaten OKU 2015 adalah mengkomunikasikan (sosialisasi dan kampanye) calon bupati dan wakil bupati yang diusung. Parpol pengusung memiliki kebijakan tersendiri mengapa mengusung paslon yang diusungnya sebagai calon bupati dan wakil bupati, kebijakan tersebut dikomunikasikan melalui facebook parpol pengusung. Kebijakan atau alasan tersebut dikomunikasikan melalui facebook agar para pendukung mengetahui alasan atau kebijakan parpol pengusung. Misalnya visi-misi paslon sesuai dan sejalan dengan harapan masyarakat, program kerjanya membumi, bebas korupsi, tidak hanya berjanji dan sebagainya.

\section{Simpulan}

Berdasarkan hasil temuan dalam pengamatan dan analisis data terhadap peran Facebook dalam kampanye pemilukada di Kabupaten OKU Sumsel pada pemilih potensial tentang calon bupati dan wakil bupati yang diusung dalam pemilukada di Kabupaten OKU Sumsel 2015. Hasil pengamatan dan analisis peneliti dapat disimpulkan bahwa peran Facebook bagi pemilih potensial adalah: (1). Sebagai sarana mencari informasi bagi pendukung tentang pasangan calon bupati dan wakil bupati dan referensi pandangan politik para pendukung dalam menjatuhkan pilihan politik terhadap pasangan calon bupati dan wakil bupati, (2). Sebagai bahan referensi mengenai informasi yang didapatkan dari media lain tentang calon bupati dan wakil bupati yang diusung, serta sebagai penghubung informasi mengenai pasangan calon bupati dan wakil bupati melalui link yang dibagikan melalui facebook parpol pengusung pasangan calon yang dapat diakses oleh pemilih potensial terkait informasi tentang pasangan calon bupati dan wakil bupati, dan (3). Sebagai sarana menyuarakan aspirasi, kritik, saran, tanggapan tentang informasi yang terkait tentang pasangan calon bupati dan wakil bupati yang akan bertarung dalam pemilukada Kabupaten OKU 2015.

\section{Daftar Pustaka}

1) Cangara, Hafid. 2011. Komunikasi Politik: Konsep, Teori, dan Strategi. Jakarta: Rajawali Press

2) Kotler, P. (2003). Marketing Management. New Jersey: Pearson Education. International, Inc.

3) McQuail, Dennis. 2012. Teori Komunikasi Massa. Terj. Putri Iva Izzati. Jakarta: Salemba Humanika

4) Mulyana, Deddy. 2007. Ilmu Komunikasi: Suatu Pengantar. Bandung: PT Remaja Rosdakarya

5) Kholid, Anwar, Rahmawati Husein, Dyah Mutiarin dan Septiyan Listiya E. R. "The Influence of Social Media Towards Student Political Participation During the 2014 Indonesian Presidential Election". Journal of Government and Politics Vol. 6 No. 2 August 2015

6) Moyser, George. 2003. Political Participation. In: Axtmann, Roland. ed. Understanding Democratic Politics: an Introduction. London: Sage, pp174-186 Dalam: Kholid, Anwar, Rahmawati Husein, Dyah Mutiarin dan Septiyan Listiya E. R. "The Influence of Social Media Towards Student Political Participation During the 2014 Indonesian Presidential Election". Journal of Government and Politics Vol. 6 No. 2 August 2015

7) Turner, Lyn H., Richard West. Pengantar Teori Komunikasi Analisis dan Aplikasi. Edisi 3 Diterjemahkan Natalia Damayanti M. 2008. Jakarta: Salemba Humanika 
8) Ardha, Berliani. 2014. "Sosial Media sebagai Media Kampanye partai Politik 2014 di Indonesia". Dalam Jurnal Visi Komunikasi Volume 13, Nomor 01, Mei 2014: 105-120. Universitas Mercua Buana, Jakarta.

9) Alatas, Salim. 2014. "Media Baru, Partisipasi Politik, dan Kualitas Demokrasi". Program Studi Digital Communication Surya University. Makalah. Dipresentasikan dalam Konferensi Nasional Komunikasi 2014, Batam 11 Maret 2014.

Internet:

10) https://www.academia.edu/6433955/MEDIA_BARU_PARTISIPASI_POLITIK_DAN_KUALI TAS_DEMOKRASI

11) http://nasional.kompas.com/read/2015/09/25/15130071/Media.Sosial.Makin.Jadi.Primadona.Ka mpanye.Pilkada

12) https://salimalatas.wordpress.com/2014/01/24/media-baru-partisipasi-politik-dan-kualitasdemokrasi/ 